\title{
У Työelämän näkökulma maahanmuuttajataustaisten lääkärien kielitaitoon
}

\author{
Kielitaidon merkitys lääkärin työssä suoriutumiselle tunnustetaan laajasti, mutta täsmällistä \\ tietoa kielitaidon käytännön vaikutuksesta työn sujuvuuteen on vain vähän. Tässä tutkimuksessa \\ maahanmuuttajataustaisten lääkärien suomen kielen taitoa tarkastellaan työelämän näkökulmasta. \\ Terveydenhuollon ammattilaisten ryhmähaastatteluiden (kuusi haastattelua, 32 haastateltavaa) \\ avulla selvitettiin, missä määrin maahanmuuttajataustaisten lääkärien mahdolliset kielitaidon \\ puutteet vaikuttavat työssä suoriutumiseen, työyhteisön toimintaan ja potilasturvallisuuteen. \\ Haastattelut analysoitiin teemoittaisella sisällönanalyysilla fenomenologisesta näkökulmasta. \\ Tutkimuksen perusteella maahanmuuttajataustaisten lääkärien kielitaito koetaan usein \\ puutteelliseksi. Se aiheuttaa ongelmia ja vaarantaa jopa potilasturvallisuutta. Kielitaidon \\ puutteellisuuden nähdään vaativan tukea mutta myös kuormittavan työyhteisöjä; erityisesti \\ hoitohenkilökunnan vastuu kasvaa liiankin suureksi. Ongelmallisimmat tilanteet kielitaidon kannalta \\ ovat potilas-lääkäri-keskustelu sekä puhelinkonsultointi. Maahanmuuttajataustaiset lääkärit ja \\ työyhteisöt tarvitsisivatkin nykyistä enemmän tukea kielitaidon puutteellisuuden huomiointiin \\ ja hallintaan.
}

\section{Asiasanat: lääkärit, maahanmuuttajatausta, kielitaito, riskit}

MAIJA TERVOLA

\section{JOHDANTO}

Suomi on monen muun teollisuusmaan tapaan nopeasti tullut riippuvaiseksi ulkomailla koulutettujen lääkärien työpanoksesta. Tällä hetkellä Suomessa asuvista lääkäreistä vajaan yhdeksän prosentin äidinkieli on jokin muu kuin suomi tai ruotsi (1). Osuus on hieman suurempi kuin koko väestössä, jossa vieraskielisiä on kuusi prosenttia (2). Sairaanhoitopiireissä maahanmuuttajataustaisten lääkärien osuus vaihtelee Keski-Suomen kahdesta prosentista Ahvenanmaan 42 prosenttiin, tyypillinen osuus on kymmenen prosentin molemmin puolin (3). Terveydenhuollon työelämässä on siis yhä useammin mukana lääkäreitä, joiden työskentelyä leimaa suomen kielen harjoittelu. Tämän myötä on lääkärien kielitaitoon ja sen riittävyyteen alettu kiinnittää huomiota yhä enemmän.
Suomalainen keskustelu maahanmuuttajataustaisten lääkärien kielitaidosta on toistaiseksi perustunut enimmäkseen yksittäistapauksiin ja mediassa raportoituihin kokemuksiin $(4,5)$. Virallisissa valituksissa kielitaito-ongelmat eivät yleensä nouse ainakaan yksinään vahinkojen syyksi (5). Englanninkielisissä maissa, joissa on pitkät perinteet ulkomailla koulutettujen lääkärien rekrytoinnissa, on kartoitettu paljon kielitaidon merkitystä lääkäri-potilas-kommunikoinnissa, ja tulokset osoittavat, että lääkärin ja potilaan kielitaidon eriparisuus nostaa potilasvahinkojen riskiä $(6,7)$. Erityisesti muuta kuin äidinkieltään käyttävien lääkärien kielitaidon on todettu aiheuttavan ongelmia $(8,9)$.

Suomessa lääkärien virallinen kielitaitovaatimus on säädetty vähäiseksi; vaadittu taso on sama kuin kansalaisuushakemuksissa (10). Epä- 
virallisia kielitaitovaatimuksia esittävät myös työnantajat, kollegat, asiakkaat, potilaat ja muut sidosryhmät. Vaatimuksista puuttuu yhtenäisyyttä, ja samalla puuttuu systemaattinen tieto siitä, millaista kielitaitoa lääkärin työssä todella vaaditaan.

Myös maahanmuuttajataustaisten lääkärien täydennys- ja kielikoulutuskäytänteet ovat osoittautuneet riittämättömiksi (11). Nykyisin käytössä oleva kielitesti ei erottele lääkäreitä kielitaidon perusteella tehokkaasti (12). Laillistamiskuulusteluissa on myös todettu kielitaidon puutteisiin liittyviä ongelmia $(12,13)$. Lääkärien täydennyskoulutus on satunnaista, ja ammatillisen kielitaidon testaus puuttuu kokonaan. Suomessa onkin viime aikoina käynnistetty hankkeita terveydenhuollon maahanmuuttajataustaisen henkilöstön koulutuksen ja testauksen arvioimiseksi ja kehittämiseksi $(14,15)$.

Tässä tutkimuksessa selvitetään, missä määrin maahanmuuttajataustaisten lääkärien kielitaito on terveydenhuollon toiminnan kannalta puutteellista ja miten mahdollinen puutteellisuus vaikuttaa terveydenhuollon arkeen sekä potilasturvallisuuteen. Lääkärien kielitaitoa lähestytään työelämän näkökulmasta; työelämää edustavat terveydenhuollon ammattilaiset, joilla on kokemusta suomalaisista terveydenhuoltoinstituutioista sekä maahanmuuttajataustaisten lääkärien kanssa työskentelystä.

Aiemmissa tutkimuksissa kielitaitokysymystä on lähestytty esimerkiksi maahanmuuttajataustaisten lääkärien omasta näkökulmasta $(8,16)$, potilaiden näkökulmasta $(6,7)$ ja viranomaisten näkökulmasta $(5,17)$. Tiedetään, että maahanmuuttajataustaisten lääkärien käsitys omasta kielitaidostaan saattaa erota potilaiden ja kollegoiden käsityksestä $(8,18)$. Suomessa toteutettujen kyselytutkimusten mukaan maahanmuuttajataustaisilla lääkäreillä on hyvin myönteinen käsitys omasta kielitaidostaan erityisesti potilaskeskusteluissa $(3,16)$. On siis tarpeen tutkia, miltä kielitaitokysymys näyttää työelämän näkökulmasta tarkasteltuna.

Tarkoitus ei ole nostaa keskiöön terveydenhuollon ammattilaisten henkilökohtaisia käsityksiä sinänsä vaan tarkastella niiden kautta lääkärien kielitaitokysymystä suhteessa terveydenhuollon työn sujumiseen. Terveydenhuollon ammattilaiset ovat työyhteisönsä edustajia, jotka näkevät niin potilaan kuin maahanmuuttajataus- taisen lääkärin sekä kollegoiden aseman mahdollisissa kieliongelmissa. Tarkastelun tulokset raportoidaan työtilanteiden ja riskien kautta. Lisäksi tarkastellaan mahdollisten kielitaito-ongelmien vaikutuksia laitosten työkäytäntöihin sekä parannusehdotuksia tulevaisuuden varalle.

\section{AINEISTO JA MENETELMÄ}

Tutkimus toteutettiin haastattelututkimuksena. Maahanmuuttajataustaisten lääkärien työhön sijoittumisesta saatiin tietoa Tampereen yliopistossa järjestettävien ETA-alueen ulkopuolella koulutettujen lääkärien laillistamiskuulusteluiden kautta. Yhteistyölaitoksiksi valittiin erityyppisiä julkisen terveydenhuollon laitoksia Etelä-, Länsija Itä-Suomen alueilta, ja yhteistyötä ehdotettiin seitsemälle laitokselle. Pääkaupunkiseudulla yhteistyöehdotus ei toteutunut; haastatteluja kertyi siis kuusi.

Haastatteluihin kutsuttiin eri ammattiryhmiä edustavia henkilöitä, joilla on kokemusta maahanmuuttajataustaisten lääkärien kanssa työskentelystä. Tässä käytettiin hyväksi laitoksen yhteyshenkilön harkintaa. Näkökulmien kattavuuden varmistamiseksi huolehdittiin, että kussakin haastattelussa on edustettuina hoitohenkilökuntaa, lääkäreitä sekä muita ammattilaisia. Yhdestä haastattelusta lääkäriedustus puuttuu, sillä kutsuttu henkilö perui viime hetkellä. Taulukossa 1 on eriteltynä laitosten tyyppi, haastateltavien määrä ja ammattiala kussakin laitoksessa.

Haastattelut toteutettiin puolistrukturoituina fokushaastatteluina $(19,20)$ vuoden 2015 aikana. Haastatteluun lupautuneille lähetettiin etukäteen täytettäväksi kyselylomake, joka toimi myös haastattelun runkona. Näin pyrittiin varmistamaan haastateltavien valmistautuminen aiheeseen. Kyselylomake sisälsi kahdeksan pääkysymystä (taulukko 2)

Kuudesta haastattelusta viisi nauhoitettiin. Nauhoitusten lisäksi aineistona ovat täytetyt kyselylomakkeet kommentteineen sekä haastattelijan tekemät muistiinpanot. Kukin haastattelu kesti 60-90 minuuttia, yhteensä haastattelunauhoitusta kertyi 6 tuntia ja 15 minuuttia. Haastattelunauhoituksista litteroitiin sisältöosuudet.

Aineistolle toteutettiin sisällönanalyysi fenomenologisesta näkökulmasta $(21,22)$. Huomio kohdistettiin erityisesti siihen, millaisia maahanmuuttajataustaisten lääkärien kielitaitoon liit- 
Taulukko 1. Laitosten tyyppi, haastateltavien määrä ja ammattiala. Suluissa on esimiestehtävissä toimivien määrä. 32 haastateltavan joukossa on 26 naista ja 6 miestä, joista 4 lääkäriä ja 2 hoitajaa.

\begin{tabular}{|l|l|l|l|l|l|l|}
\hline \multirow{2}{*}{$\begin{array}{l}\text { Laitoksen } \\
\text { numero }\end{array}$} & \multirow{2}{*}{ Laitoksen tyyppi } & \multicolumn{2}{|l|}{ Haastateltavien ammattiala } & \multirow{2}{*}{ Yhteensä } \\
\cline { 3 - 7 } & & Lääkärit & Hoitohenkilökunta & Sihteerit & Muut & \\
\hline 1 & Terveyskeskus & $2(1)$ & 3 & - & - & $5(1)$ \\
\hline 2 & Terveyskeskus & $2(1)$ & 3 & 1 & - & $6(1)$ \\
\hline 3 & Kaupunginsairaala & $2(1)$ & $2(1)$ & 1 & - & $5(2)$ \\
\hline 4 & Kaupunginsairaala & $1(1)$ & $3(1)$ & 1 & $1 *$ & $6(2)$ \\
\hline 5 & Mielisairaala & $1(1)$ & $3(1)$ & 1 & - & $5(2)$ \\
\hline 6 & Keskussairaala & - & $4(2)$ & - & $1 * *$ & $5(2)$ \\
\hline YHTEENSÄ & & $8(5)$ & $18(5)$ & 4 & 2 & $32(10)$ \\
\hline
\end{tabular}

* Fysioterapeutti, * Palvelukoordinaattori

Taulukko 2. Tutkimushaastattelun pääkysymykset.

\begin{tabular}{|l|l|}
\hline 1) & $\begin{array}{l}\text { Arvioi kohtaamiesi maahanmuuttajataustaisten lääkärien suomen kielen taitoa. } \\
\text { Kuinka yleisiä ovat arviosi mukaan puutteet kielitaidon eri osa-alueissa? }\end{array}$ \\
\hline 2) & $\begin{array}{l}\text { Kuinka usein käsityksesi mukaan esiintyy kielitaidon puutteellisuudesta johtuvia } \\
\text { ongelmia eri työtilanteissa? }\end{array}$ \\
\hline 3) & Kuinka usein arvioit kohtaavasi vakavia kielitaidon puutteista johtuvia ongelmia? \\
\hline 4) & $\begin{array}{l}\text { Jos olet joskus kohdannut kielitaidon puutteesta johtuvia vaarallisia tilanteita, } \\
\text { kuvaile yhtä tai kahta tilannetta. }\end{array}$ \\
\hline 5) & $\begin{array}{l}\text { Kuinka vakava ongelma maahanmuuttajataustaisten lääkärien suomen kielen } \\
\text { taidon mahdolliset puutteet ovat kokemuksesi perusteella yleisesti? }\end{array}$ \\
\hline 6) & $\begin{array}{l}\text { Millainen merkitys mielestäsi on muilla maahanmuuttajataustaisen lääkärin työssä } \\
\text { menestymiseen vaikuttavilla seikoilla, kuten ammattitaidolla, luonteenpiirteillä, } \\
\text { ihmissuhdetaidoilla tai kulttuurisella sopeutumisella? Millainen on mielestäsi } \\
\text { niiden suhde varsinaiseen suomen kielen taitoon nähden? }\end{array}$ \\
\hline 7) & Millaisia ratkaisuja kielitaito-ongelmiin on käytetty työyhteisössäsi? \\
\hline 8) & $\begin{array}{l}\text { Millaisia toimenpiteitä ehdottaisit maahanmuuttajataustaisten lääkärien kielitaito- } \\
\text { ongelmien helpottamiseksi tai ennaltaehkäisemiseksi? }\end{array}$ \\
\hline
\end{tabular}

tyviä asiaintiloja ja tapahtumia haastateltavat ovat havainneet ja millaisia merkityksiä ja vaikutuksia he niillä näkevät (23). Aineistosta eriteltiin teemat eli ilmaukset, joilla haastateltavat viittaavat puheena oleviin ilmiöihin (20). Teemat muotoiltiin koodisanoiksi, jotka luokiteltiin yhdeksään luokkaan (taulukko 3).

Koodit eivät ole kattavia eivätkä keskenään symmetrisiä vaan ne viittaavat asioihin, jotka haastateltavat ovat maininneet. Aineisto paloiteltiin jaksoiksi, jotka analysoitiin koodien avulla merkitsemällä kuhunkin jaksoon siihen sisällöllisesti liittyvät koodit. Näin saatiin näkyviin työtilanteiden ja niihin liittyvien tekijöiden väliset yhteydet.

\section{TULOKSET}

\section{POTILASVASTAANOTTO JA PUHELINKONSULTOINTI ONGELMALLISIMMAT TILANTEET}

Yleisesti maahanmuuttajataustaisten lääkärien kielitaitopuutteita pidettiin kohtalaisena tai vakavana haasteena laitosten toiminnassa. Ongelmia olivat kohdanneet kaikki, vaikka kielitaidon yksilöllinen vaihtelu tunnustettiin suureksi. Yhtenä ongelmallisimmista tilanteista lääkärin kielitaidon kannalta pidettiin potilaskeskustelua. Ongelmia nähtiin sekä tuottamisessa että ymmärtämisessä: potilas ei ymmärrä, mitä lääkäri sanoo, eikä lääkäri ymmärrä, mitä potilas sanoo. 
Taulukko 3. Sisällönanalyysin koodit. Koodit ovat peräisin haastateltavien puheesta eivätkä kata ilmiöiden koko laajuutta.

\begin{tabular}{|c|c|c|c|c|c|c|}
\hline \multirow{2}{*}{$\begin{array}{l}\text { Luokka } \\
\text { Osallistujat }\end{array}$} & \multicolumn{6}{|l|}{ Analyysikoodit } \\
\hline & $\begin{array}{l}\text { Lääkäri- } \\
\text { lääkäri }\end{array}$ & $\begin{array}{l}\text { Lääkäri- } \\
\text { hoitaja }\end{array}$ & $\begin{array}{l}\text { Lääkäri- } \\
\text { esimies }\end{array}$ & $\begin{array}{l}\text { Lääkäri- } \\
\text { potilas }\end{array}$ & $\begin{array}{l}\text { Lääkäri- } \\
\text { omaiset }\end{array}$ & $\begin{array}{l}\text { Lääkäri- } \\
\text { viranomaiset }\end{array}$ \\
\hline $\begin{array}{l}\text { Erilaiset } \\
\text { potilaat }\end{array}$ & Vanhukset & $\begin{array}{l}\text { Mielenterveys- } \\
\text { potilaat }\end{array}$ & $\begin{array}{l}\text { Alzheimer- } \\
\text { potilaat }\end{array}$ & & & \\
\hline Potilaan tila & Huono kuulo & $\begin{array}{l}\text { Jännitys, } \\
\text { ahdistus }\end{array}$ & $\begin{array}{l}\text { Negatiivinen } \\
\text { asenne }\end{array}$ & & & \\
\hline Tilanteet & \begin{tabular}{|l|} 
Potilas- \\
vastaanotto
\end{tabular} & Potilaskierto & $\begin{array}{l}\text { Kollegan } \\
\text { konsultointi }\end{array}$ & $\begin{array}{l}\text { Kokoukset } \\
\text { ja palaverit }\end{array}$ & $\begin{array}{l}\text { Epäviralliset } \\
\text { tilanteet }\end{array}$ & \\
\hline Tekstit & Sähköpostit & $\begin{array}{l}\text { Potilasasia- } \\
\text { kirjat }\end{array}$ & Lausunnot & Lähetteet & Ohjeet & $\begin{array}{l}\text { Laki- ja } \\
\text { säädöstekstit }\end{array}$ \\
\hline $\begin{array}{l}\text { Tilanteiden } \\
\text { ominaisuu- } \\
\text { det }\end{array}$ & $\begin{array}{l}\text { Kanava } \\
\text { - kasvokkain } \\
\text { - etäyhteys }\end{array}$ & $\begin{array}{l}\text { Akustiset } \\
\text { - kaiku } \\
\text { - häly }\end{array}$ & $\begin{array}{l}\text { Sosiaaliset } \\
\text { - tuttuus } \\
\text { - ryhmä- } \\
\text { tilanteet }\end{array}$ & Aika & Kollegan tuki & Uusi tilanne \\
\hline $\begin{array}{l}\text { Kielelliset } \\
\text { tekijät }\end{array}$ & $\begin{array}{l}\text { Puhe } \\
\text { - tuotto } \\
\text { - ääntäminen } \\
\text { - ymmärtä- } \\
\quad \text { minen } \\
\text { - eleet ja ilmeet }\end{array}$ & $\begin{array}{l}\text { Kirjoitus } \\
- \text { tuotto } \\
\text { - oikein- } \\
\quad \text { kirjoitus } \\
\text { - lukeminen }\end{array}$ & $\begin{array}{l}\text { Kielioppi } \\
\text { - rakenteet } \\
\text { - sana- } \\
\text { järjestys } \\
\text { - taivuttamat- } \\
\text { tomuus }\end{array}$ & $\begin{array}{l}\text { Sanasto } \\
\text { - sävyerot } \\
\text { - vertaus- } \\
\quad \text { kuvat } \\
\text { - sanonnat } \\
\text { - huumori }\end{array}$ & $\begin{array}{l}\text { Abstraktio- } \\
\text { taso }\end{array}$ & $\begin{array}{l}\text { Monitulkintai- } \\
\text { suus }\end{array}$ \\
\hline $\begin{array}{l}\text { Kielitaidon } \\
\text { puutteiden } \\
\text { seuraukset }\end{array}$ & $\begin{array}{l}\text { Väärä } \\
\text { diagnoosi / } \\
\text { hoito }\end{array}$ & $\begin{array}{l}\text { Viivästynyt } \\
\text { diagnoosi / } \\
\text { hoito }\end{array}$ & $\begin{array}{l}\text { Työ lisääntyy } \\
\text { - uusi } \\
\text { vastaan- } \\
\text { ottoaika }\end{array}$ & Vaaratilanne & $\begin{array}{l}\text { Ahdistus, } \\
\text { epävarmuus }\end{array}$ & $\begin{array}{l}\text { Hoitajien suuri } \\
\text { vastuu }\end{array}$ \\
\hline $\begin{array}{l}\text { Epävarmuu- } \\
\text { den merkit }\end{array}$ & $\begin{array}{l}\text { Tekstien } \\
\text { kopioiminen }\end{array}$ & $\begin{array}{l}\text { Hiljaisuus, } \\
\text { kantaaotta- } \\
\text { mattomuus }\end{array}$ & $\begin{array}{l}\text { Ymmärtämät- } \\
\text { tömyyden } \\
\text { piilottaminen }\end{array}$ & $\begin{array}{l}\text { Tilanteiden } \\
\text { välttely }\end{array}$ & & \\
\hline
\end{tabular}

”Kyllä mä oon sitä mieltä, että potilaalle puhuminen ja potilaan puheen ymmärtäminen, siinä se suurin ongelma ilman muuta on." $(\mathrm{MS}-\mathrm{S} 1)^{1}$

"Kyllä ihan tossa päivittäises työssä näissä potilasvastaanotoissa, tarkottaa näitä edellä kuvattuja tilanteita, että lääkäri kiertää ja tapaa potilaita, niin kyllä sitä ongelmaa on, että miten lääkäri ymmärtää potilaan sanomaa tai hoitotyöntekijän sanomaa tai toisin päin.” (KS-H10)

"Potilas saattaa kysyä lääkäriltä jotain, ja vieraskielinen lääkäri ymmärtää sen väärin, vastaa aivan toiseen asiaan. Että sitten pitää taas

\footnotetext{
${ }^{1}$ Sulkuihin on merkitty laitoksen ja haastateltavan yksilöintitunnukset. Merkinnöissä käytetään seuraavia lyhenteitä: $\mathrm{KES}=$ keskussairaala, $\mathrm{KS}=$ kaupunginsairaala, MS=mielisairaala, TK=terveyskeskus; $\mathrm{H}=$ hoitohenkilö, $\mathrm{L}=$ =lääkäri, $\mathrm{S}=$ sihteeri, $M=$ muu.
}

hoitajan olla siinä valppaana ja hereillä, että puhutaan oikeista asioista. Just kaikista murteistakin johtuen.” (KES-H2)

Ongelmat tulevat näkyviin selvimmin hoitohenkilökunnan kautta. Hoitajat toimivat monesti lääkärien työparina tai ovat muutoin läsnä potilaan ja lääkärin välisissä kommunikointitilanteissa, jolloin he havainnoivat ruohonjuuritasolla lääkärin ja potilaan välistä kanssakäymistä. Potilasvastaanoton kieliongelmista tulee myös palautetta esimiehille niin potilailta kuin lääkäreiltä itseltäänkin. Lisäksi ongelmat tulevat näkyviin epäsuorasti: Potilas tulee vastaanotolle uudestaan, koska kokee, että hänen asiansa ei selvinnyt maahanmuuttajataustaisen lääkärin vastaanotolla. Potilas turvautuu hoitohenkilökunnan apuun jäätyään ymmälleen lääkärin vastaanoton jälkeen. Jälkeenpäin saattaa käydä ilmi, että vastaanotolla 
hoidettiin jotain muuta vaivaa kuin mitä potilaalla oli mielessä.

Kaikkein eniten potilasturvallisuuteen liittyvää huolta haastateltavissa aiheutti puhelinkonsultointi. Puhelimitse asiointi nähtiin hankalana sekä potilaiden ja lääkärin välillä että kollegoiden välillä.

"Kyllähän toi puhelimessa asiointi on se kaikkein vaikein asia." (KS1-L2)

"Moni asiakas sanookin, että ei puhelinaikaa, että hän ei ymmärrä yhtään mitään.” (TK1-H18)

”Täältä nousee ihan selvästi sellaseks ongelmakohdaks toi puhelinkonsultointi, ja tää nyt ehkä kilpistyy siihen päivystävän lääkärin yhteydenottoihin, että kun virka-ajan ulkopuolella hoitotyöntekijät sitten soittaa tuonne keskussairaalaan, jossa usein päivystävänä lääkärinä on ulkomaalaistaustainen, niin ne ei kyllä mitään ongelmattomia tilanteita ole ollut, että tulee ymmärretyksi puolin ja toisin. Ja sitten ne määräykset, että ne toteutuu niin kuin on tarkoitus toteutua. Se on semmonen, mikä on noussu mulla niin että mä oon laittanut ihan että yhtenään on ongelmia.” (KS1-H10)

"Puhelinmääräykset on mun mielestä tosi vaarallisia, elikkä ne pitää saada kirjallisina.” (KES-H2)

Tyypillisessä tilanteessa vuodeosaston sairaanhoitaja soittaa päivystävälle lääkärille toiseen sairaalaan tai osastolle, kun potilaan tilassa tapahtuu muutos. Tällöin lääkäri joutuu muodostamaan kuvan potilaan tilasta hoitajan suullisen kuvauksen perusteella. Puhelimitse annettavat lääke- ja hoitomääräykset ovat haastateltavien mukaan hyvin riskialttiita ja edellyttävät vastaanottavalta hoitohenkilöltä suurta varovaisuutta.

\section{ONGELMAT POTILASASIAKIRJOISSA, OHJEIDEN TULKITSEMISESSA JA KOKOUKSISSA AIHEUTTAVAT LISÄTYÖTÄ}

Kielitaidon puutteellisuuteen liittyviä ongelmia esiintyy haastateltavien mukaan myös potilasasiakirjoissa ja lausunnoissa, vaikka niiden ei katsottu aiheuttavan suoraa riskiä potilaan hoidolle. Asiakirjojen ongelmat ovat haastateltavien mukaan kuitenkin ajoittain vakaviakin.
”Kyllä näissä lausunnoissa on luvattoman usein ihan asiavirheitä, just sen takia, että ei tunneta lauserakenteita oikein, niin sitten yksi lause voi tarkoittaa kahta asiaa. Mut onneksi ne sitten yleensä palautuu takaisin ja eihän ne nyt yleensä potilaan henkeä uhkaa, mutta ne on vaan ikäviä korjata, ja aiheuttaa monille työtä, kun niitä palautellaan tuolta pitkin maailmaa, maistraatista ja Kelalta, että ei he ymmärrä tästä.” (KS1-L2)

"Joskus menee sekasin näissä lausunnoissa se, että mitä potilas on kertonut ja mitä lääkäri on todennut, että ne tietysti pitäis erottaa sieltä jotenkin.” (KS2-L5)

Asiakirjojen virheet ehditään hoitoketjussa useimmiten havaita ja korjata. Lisäksi kirjoittamisen prosessiluonne mahdollistaa kielellisten kysymysten selvittämisen jo laatimisvaiheessa. Vaikka epäselvistä asiakirjoista harvoin aiheutuu suoranaista vaaraa potilasturvallisuudelle, ne lisäävät työn määrää ja vaativat koko hoitoketjulta ylimääräistä valppautta.

Monitulkintaisuutta ja vaikeaselkoisuutta esiintyy myös saneluissa. Saneluiden puhtaaksikirjoittajat korjaavat havaitsemiaan virheitä ja kysyvät tarvittaessa tarkennusta sanelleelta lääkäriltä.

"Sitten kun mä kirjotan niitä [saneluita] niin mulle joskus kyllä tulee semmonen, että kumpaakohan tässä nyt tarkotetaan, et kun siinä tulee päätteitä ja ei-sanoja ja semmosia peräkkäin, että niinku suomalaista lausetta ei tule niistä. (KS2-S4)

Ohjeiden tulkitsemisessa esiintyy haastateltavien mukaan ongelmia, jotka tulevat esiin erityisesti silloin, kun ohjeistus on muuttunut. Ongelmat ilmenevät tavallisesti epäsuorasti siten, että ohjeen antamisen jälkeen havaitaan lääkärin toiminnasta tai puheesta, että ohjetta ei ollutkaan ymmärretty.

"Kyllä mä joudun tulla apuun, kun joku taksikorttiasia mikä nytki tuli uus, että vaikka se oli kyllä kokouksessa käyty läpi, mutta sitte ku se käytännössä tulee ensimmästä kertaa eteen, ni kyllä se joudutaan menee ihan uudestaan vielä.” (TK1-H18) 
Kokouksista ja palavereista monilla haastateltavilla oli tuntemus, että ymmärrysvaikeuksia esiintyy. Niitä epäiltiin sillä perusteella, että maahanmuuttajataustaiset lääkärit ovat useimmiten hiljaa kokouksissa ja heidän omat harvat puheenvuoronsa ovat ympäripyöreitä ja epätäsmällisiä. Ymmärryksen puute saattaa niin ikään tulla ilmi jälkeenpäin, kun puheena olleeseen asiaan palataan käytännön työssä.

"Varmaan se, että on palaverissa hiljaa, niin todennäköisesti johtuu siitä, että ei oikein pysy kärryillä, että mistä täällä puhutaan. Jos moni puhuu päällekkäin ja on vähän hälinää, niin kyllä sitä varmaan on vaikee seurata.” (KS2-L6)

"Kuntoutuspalavereissa on tullut tämmönen, että ollaan ihan puhumattomia. Että se vastuu on ollu sitten hoitohenkilökunnalla ja fysioterapeutilla. Että hän [maahanmuuttajataustainen lääkäri] ei ota kantaa, niin en tiedä johtuuko se sitten uskalluksesta vai ymmärryksestä myös. Että annetaan muiden hoitaa puhuminen. Ja kun kuntoutuspalaverissa sitten yleensä sovitaan näitä tavotteita ja millä jatkosuunnitelmalla edetään, niin sitten oon huomannut jälkeenpäin, että ei oo sit tosiaan ollutkaan sitä ymmärrystä siinä tilanteessa.” (KS1-M2)

\section{KOLLEGAN KANSSA KESKUSTELU VÄHITEN ONGELMALLISTA}

Selvästi ongelmattomampana pidettiin kollegoiden välistä kasvokkaista keskustelua. Haastateltavat kokivat itse pärjäävänsä maahanmuuttajataustaisen lääkärin kanssa potilaita ja omaisia paremmin. He huomaavat väärinymmärryksiä ja osaavat korjata niitä. Erityisesti toisen lääkärin kanssa keskustelu lääketieteellisistä aiheista koettiin vaivattomaksi.

"Se mihin mä oon laittanu et usein tulee ongelmia, on just tää potilasvastaanotto, sen takii et mä en oo itse siel sillon paikalla. Et ei musta [kollegoiden välisessä] kasvokkaiskonsultoinnissa tai raportoinnissa ikinä mitään tai hyvin harvoin mitään ongelmii on, ku asiat keskustellaan näin ja useimmiten pystyy saamaan selvyyttä siihen tilanteeseen.” [MS-L1]
"Potilaat eivät ymmärrä, hoitajat kyl pystyy tarkentavia kysymyksiä tekemään, joutuvat tekemään, jotta pystyvät ammatillisesti toimimaan, ettei tule lääkintä- tai muita virheitä. Mut potilaat ei siinä kiireessä pysty kysymään, kun lääkäri on jo mennyt pois. Eli potilaat jäävät heikommalle kuin hoitajat, kielellisesti.” (KES-H2)

Melko ongelmattomiksi koettiin myös epäviralliset keskustelut. Haastattelujen perusteella monet maahanmuuttajataustaiset lääkärit osallistuvat mielellään keskusteluihin esimerkiksi kahvitauoilla. Tosin tämä nähtiin myös persoonakysymyksenä, toiset ovat innokkaampia osallistumaan vapaamuotoisiin tilanteisiin kuin toiset.

"Tietysti ne epäviralliset tilanteet on ehkä helpompia, kun siinä on niinku epämuodollisempaa ja siinä ollaan tekemisissä työtovereiden kanssa, mut sit potilaiden kanssa, esim. vastaanotolla, niin siellä sitten enemmän tulee niitä ongelmia.” (KS2-H14)

"Tietysti noissa epävirallisissa keskusteluissa se [kielitaidon heikkous] ei nyt niin haittaa, ku ehkä he osaa tätä small talkia sit kuitenki paremmin.” (KS1-L2)

Epävirallisia keskustelutilanteita pidetään yleisesti myös tärkeänä kielitaitoa kehittävänä harjoitteluna ja niihin kannustetaan osallistumaan. Niiden koetaan myös ehkäisevän ennalta kielitaidon kapeutumista pelkäksi ammattikielen hallinnaksi.

\section{HOITOHENKILÖKUNTA VARMISTUSTAHONA}

Kaikissa haastatteluissa korostettiin, että maahanmuuttajataustaisten lääkärien kielitaidon puutteellisuudesta seuraa vakavia potilasvahinkoja vain harvoin. Haastateltavien mukaan syynä varsinaisten potilasvahinkojen vähyyteen ovat työyhteisössä muodostuneet erilaiset varmistusmekanismit. Hoitoprosesseissa on useita vaiheita, joissa varmistetaan määräysten ja niiden toteutuksen oikeellisuus. Mahdolliset virheet pystytään korjaamaan ennen kuin niistä koituu haittaa potilaalle.

Erityisesti painotettiin hoitohenkilökunnan merkitystä varmistustahona. Koska hoitajat 
työskentelevät läheisessä kontaktissa potilaiden ja lääkärien kanssa, he huomaavat parhaiten kommunikointiongelmia potilaan ja lääkärin välillä. He selvittävät havaitsemiaan väärinymmärryksiä, tulkkaavat ja varmistavat, että osapuolet ymmärtävät toisiaan.

"Lähes sataprosenttisesti se keskustelu käydään sen vastaanottotilanteen jälkeen vielä uudestaan [potilaan kanssa] läpi, mitä siellä ihan oikeesti puhuttiin, vielä kerran vähintään.” (MS-H6)

"Tulee just kysyttyä potilaaltakin, että ymmärsitkö sä, vaikka päivystyksessä, että tuliko nyt selväksi, mitä piti tehdä, tai että ymmärsitkö asiat ja ohjeet, mitä pitää tehdä kotona ja mitkä lääkkeet pitää ottaa. Kun tavallaan suomalaisten lääkäreitten kanssa ei oo sitä ongelmaa ollut. Että tää tosiaan opettaa erilaisia asioita.” (TK1-H16)

”Ja kierroilla ihan säännöllisesti sinä [hoitaja] toimit potilaan tulkkina siinä, lääkäri puhuu ja sitten sinä selvennät potilaalle. Että kun sanotaan, että 'teillä on nyt ollut tämä insuffisientti cordis pitempään', niin potilas: 'Mikä, onks mulla joku uusi tauti? Mikä se on se mun uusi tauti?’. Multa on tälleen kysytty esim. viime viikolla. Vastasin, että ei ollut uutta sairautta, se oli se sama [sydämen vajaatoiminta].” (KES-H1)

Hoitajien vastuu ulottuu toisinaan myös lääkärin vastuun alueelle, kun he joutuvat arvioimaan lääkäriltä saamansa määräyksen oikeellisuutta. Erityisesti puhelimitse annetut määräykset herättävät hoitajissa epävarmuutta ja tarpeen tarkistaa määräyksen paikkansa pitävyys. Näissä tilanteissa potilasturvallisuuden heikkeneminen on todellinen uhka.

"Hoitaja ensin katsoo sen [määräyksen] ja miettii, että voiko tää olla näin. Ja niitä tilanteita sit pelkää, että jos ei oo kokemusta hoitajalla, tarkotan viikonloppu-, ilta-aikoina, että jos se lähtee toteuttamaan niin... Yleensähän on toinen kollegakin, mutta on tilanteita, että on kaksi vähemmän kokenutta, ja jos ei oo sitä ymmärrystä, tai lähet soittaa jonnekin muualle tai... niin näitä on ollut.” (KS1-H8)
Hoitohenkilökunnan voima kommunikaation onnistumisen varmistajana heikkenee erityisesti silloin, jos hoitajina on kokemattomia tai kielitaidoltaan epävarmoja henkilöitä. Lisäksi riskitilanteita syntyy elvytys- ja muissa kiiretilanteissa, joissa ei ole aikaa selvittää kielen merkityksiä. Hoitajat kuormittuvat ylimääräisestä työstä ja epävarmuudesta, ja haastattelutilanteessa muutamat hoitajat olivatkin selvästi kiihdyksissään kertoessaan kokemuksistaan.

"Hoitajat väsyy tähän jatkuvaan neuvontaan, valvontaan ja vastukseen.” (KES-H3)

"Ne selkeät graavit virheet se puskuri kyl tunnistaa sieltä, mut että sit välillä jää kumminkin semmonen tunne, että mitä jos sieltä välistä sit meneekin niitä läpi. Et se verkko sit pettääkin siellä.” (KS1-H10)

"Vakavia lääkevirheitä voi sattuu, ja jos ei oo tuntosarvet pystyssä oleva hoitaja, ni vois tulla ihan kuolemantapauksiaki niissä lääkinnällisissä asioissa. Tietysti tietyt [lääke]määrät pistää jo silmään ja korvaan, täytyy siis ammatillisesti pistää, mutta voi alkumetreillä käydä niin että ei osaa kyseenalaistaa lääkärin määräystä. Tai uskalla kyseenalaistaa lääkärin määräystä. Et sit puhutaan vakavista... En tiiä onko täällä käyny mutta mahdollista on.” (KES-H2)

Maahanmuuttajataustaisten lääkärien kielitaidon puutteellisuudesta aiheutuvat ongelmat eivät siis juurikaan näy virallisissa tilastoissa, vaan tavallisesti ne pystytään havaitsemaan ja korjaamaan heti. Vaikka ongelmat jäävät suurimmaksi osaksi näkymättömiin, potilasturvallisuuden vaarantuminen on ilmeistä.

”Näitä on mennyt toteutukseen, näitä vaarallisia määräyksiä.” (KS1-H8)

"Haittailmoituksia tehdään liian vähän. Et jos näitä läheltä piti -tilanteita ilmotettais, niin nehän olis just näitä [maahanmuuttajataustaisen lääkärin kielitaitoon liittyviä].” (KES-H3)

Henkilöiden tuttuudella nähtiin olevan merkitystä kieliongelmien ilmenemisessä. Mitä pitempään henkilöt ovat työskennelleet yhdessä, sitä vähemmän kieliongelmia koettiin ilmenevän. Tämän 
mainittiin koskevan sekä kollega- että potilassuhteita.

"Se on aina, et mitä pidempään jonkun kaa työskentelee, ni sen paremmin oppii sit ymmärtämään. Et satunnaisessa kohtaamisessa voi olla hyvinki vaikee ymmärtää, mutta sit ku pääsee taas niinku samalle aaltopituudelle, sit se paranee." [KS2-L6]

"Kyllä ihmeen hyvin on kumminki mun mielestä sujunut, ja paremmin nyt kun on pari vuotta kulunut, kun on tätä työtä tehty [yhdessä], ni sitte vaan täytyy kysyä se toinen kerta ja selventää sitä asiaa, kun toinen kysyy, mikä se sana nyt onkaan. [Haastattelija: Nii siihen tottuu vai?] Joo. Ja potilaatkin tottuu.” [TK1-H16]

Tässä raportoidut näkemykset toistuivat kaikissa haastatteluissa jossain muodossa eikä niille esiintynyt ristiriitaisia näkemyksiä. Suurin erimielisyys aineistossa muodostui siitä, kuinka vakavana kielitaito-ongelmaa pitää: maahanmuuttajataustaisten lääkärien kanssa ruohonjuuritason potilastyötä tekevät hoitajat pitivät kielitaitopuutteita vakavampana ongelmana ja kertoivat vakavammista ongelmatapauksista kuin lääkärit ja esimiesasemassa olevat. Hoitajat kertoivat suoraan havaitsemistaan ongelmista potilaiden ja maahanmuuttajataustaisten lääkärien välillä, lääkäreillä ja esimiesasemassa olevilla oli kokemusta lähinnä kollegiaalisesta kanssakäymisestä sekä potilailta tai työntekijöiltä tulevista valituksista. Sairaalaympäristössä työskentelevät hoitajat kertoivat vakavammista ongelmista kuin terveyskeskuksissa työskentelevät. Sukupuolten tai virkaiän välisiä eroja ei tullut näkyviin.

\section{EHDOTUKSIA MAAHANMUUTTAJATAUSTAISTEN LÄÄKÄRIEN KIELITAIDON KEHITTÄMISEN JA PAREMMAN SOPEUTUMISEN EDISTÄMISEKSI}

Monet haastatteluun osallistuneista laitoksista ovat oma-aloitteisesti pyrkineet sopeuttamaan käytänteitään vastaamaan paremmin haasteita, joita työyhteisön monikulttuuristuminen on tuonut mukanaan. Kaikissa haastatteluissa tärkeänä toimena pidettiin kollegoiden välisen kasvokkaisen keskustelun lisääntymistä ja tarkentumista. Se, että suomalaistaustaiset ja kokeneemmat kollegat kysyvät, tarkistavat ja selittävät asioita, nähdään itsestään selvänä ja tärkeänä keinona ehkäistä ennalta kommunikaatio-ongelmia. Lisäksi sen koetaan edesauttavan maahanmuuttajataustaisten lääkärien kielitaidon kehittymistä. Toisaalta kollegoiden resursseja maahanmuuttajataustaisten lääkärien tukemiseen pidetään osin riittämättöminä.

"Sit ku on omaksunu semmosen työtavan, et pyrkii tarkistamaan [maahanmuuttajataustaisten lääkärien laatimia] tekstejä, tarjoutuu tarkistamaan tekstejä, tarjoutuu mahdollisimman paljon oleen tekemisissä ja konsultoimaan kasvokkain ja muuta, ni niitä ongelmia ei sit tuu kauheen usein, ellei sit pidä ongelmana sitä et sit joutuu tekemään sitä paljon. Mä oon ajatellu, et se on tässä kohtaa aika tärkee osa mun työtä.” (MS-L1)

"Maahanmuuttajalääkärit tarvitsisivat tällä hetkellä enemmän tukea kuin työyhteisö pystyy antamaan.” (MS-H7)

Kaikissa haastatteluissa nostettiin keskeisenä kehittämiskohteena esiin kielitaidon lähtötaso.

"Joskus sitä vaan ihmettelee, että minkälainen se kielikurssi tai -koe mahdollisesti on, että miten tämä ihminen on voinut päästä siitä läpi. Jotenkin siihen pitäisi satsata enemmän. [--] Et pitäisi olla parempi se kielitaito siinä vaiheessa, kun tulee töihin.” (TK1-L7)

"Se kielitaitovaatimus voisi olla hiukan korkeempi, että ei liian aikaisin joutuisi tai pääsisi tänne oikeitten potilaitten pariin, että se voi lähtee sitten vähän väärille urille heti alusta.” (KS2-L6)

”Ja sitten tämä kielikoevaatimus, kyllä se musta saisi olla tarkempi, että siellä painotettaisiin lääkäreillä nimenomaan tätä ammattisanastoa ja sairaalasanastoa, terveydenhuollon sanastoa enemmän.” (KS1-H8)

Toisaalta joissain haastatteluissa korostettiin, että kielitaidon lähtötason perusteella ei voi ennusta tulevaisuuden kehitystä. Monet seikat vaikuttavat siihen, että yksilölliset kielitaitoerot lääkärien välillä kasvavat suuriksi. 
"Kuitenki sitä vaihteluvälii on niin valtavasti. Et jollain se on todella heikkoa ja jollain jo vahvaa se suomen kieli ja pitkä yhteistyö taustalla, ni ne tuo niitä vivahteita sinne." (KS1-H10)

Haastateltavat nostivat oma-aloitteisesti esiin myös lääkärin oman asenteen sekä työyhteisön tuen merkityksen. Useiden haastateltavien mukaan niin kielitaidon kehittäminen, kulttuurinen sopeutuminen kuin viime kädessä työssä menestyminenkin ovat pitkälti kiinni lääkärin omasta asenteesta.

”Mulla on tosi hyviä kokemuksia lääkäristä, jonka suomen kielen taito on aivan huikeesti noussu vuoden aikana, ja hän on halunnu oppii, hän haluu oppii, kaikki kirjotusvirheet hän käy läpi ja hänellä on loistava suomen kielen taito tällä hetkellä. Kyllä se on myös tosi iso asennekysymys." (MS-H6)

”Kun mä nään, et se lääkäri oikeesti haluu oppii sitä kieltä, on aktiivinen ja kysyy eikä oo yhtään ylimielinen, ni sellasta ihmistä todella mielellään auttaaki. Et se lähtee se vuorovaikutus siitä.” (KES-H1)

Lääkärin oma positiivinen ja aktiivinen asenne saa työyhteisön suhtautumaan avuliaasti ja positiivisesti, ja toisaalta työyhteisön tuki ja kannustus saa maahanmuuttajalääkärin panostamaan työhönsä ja kielitaitonsa kehittämiseen tarmokkaammin. Tällöin voi syntyä positiivinen kierre, joka ruokkii niin kielitaidon kehittymistä kuin muutoinkin työympäristöön sopeutumista.

\section{POHDINTA}

Tämän tutkimuksen mukaan terveydenhuollon ammattilaiset näkevät maahanmuuttajataustaisten lääkärien kielitaidossa puutteita, jotka vaikuttavat terveydenhuollon työyhteisöjen toimintaan. Pääasialliset negatiiviset vaikutukset ovat lisääntynyt työmäärä, lisääntynyt epävarmuus sekä potilasturvallisuuden heikkeneminen. Kaikkein altteimpina potilasturvallisuutta vaarantaville kieliongelmille pidettiin potilas-lääkäri-keskustelua sekä puhelinkeskustelua. Potilasasiakirjoissa sekä kokouksissa ja palavereissa esiintyy ongelmia, mutta ne eivät yleensä suoraan vaaranna potilasturvallisuutta. Kollegoiden välistä keskus- telua ja epävirallisia tilanteita pidettiin helpompina.

Tulokset tukevat väitteitä siitä, että terveydenhuollon kielitaito-ongelmat tulevat useimmiten ilmi juuri potilastyössä (24). Kuitenkin Suomessa toteutetuissa kyselytutkimuksissa yli 90 prosenttia maahanmuuttajalääkäreistä vastasi, että selviää suomen kielellä kanssakäymisestä potilaiden kanssa melko tai erittäin hyvin $(3,16)$. Epäsuhta voi liittyä eri näkökulmiin; maahanmuuttajalääkärit saattavat arvioida pärjäämistä erilaisin kriteerein kuin työyhteisön jäsenet. On myös mahdollista, että lääkärit kokevat potilaskeskustelun kielellisesti helpommaksi kuin se onkaan, koska se on tuttu, usein toistuva ja selväpiirteinen tilanne. Lisäksi on mahdollista, että lääkärin auktoriteetti- ja asiantuntija-asema potilaaseen nähden pitävät yllä tilanteen sujuvuutta kielellisistä epätarkkuuksista huolimatta. Poikkeama maahanmuuttajataustaisten lääkärien oman kielellisen pärjäämisen kokemuksen ja potilaiden kokemuksen välillä on todettu myös kansainvälisessä tutkimuksessa $(8,18)$.

Tutkimus vahvistaa muualla saatuja tutkimustuloksia siitä, että kielikysymykset ovat suuri kompastuskivi monietnisissä työyhteisöissä $(6,7$; Suomen osalta 16,24-25). On osoitettu, että lääkärin ja potilaan kielitaidon eriparisuus nostaa hoitovirheiden riskiä $(6,7,26-27)$. On myös todettu, että maahanmuuttajalääkäreillä on työssään kieleen liittyviä ongelmia siitä huolimatta, että he ovat suorittaneet vaaditut kielikokeet hyväksytysti $(8,9)$. Tämä tutkimus vahvistaa viestiä terveydenhuollon kielitaitokysymyksen ongelmallisuudesta ja täsmentää kuvaa erityisesti lääkärien kielitaidon kannalta. Tutkimuksen perusteella tilannetta voi pitää vakavana, sillä ongelmia esiintyy potilastyön kannalta keskeisissä tilanteissa. Esimerkiksi potilaan ja lääkärin välinen keskustelu on tärkeä osa lääkärin työnkuvaa; se on olennainen, toisinaan jopa ainoa tutkimusväline.

Tutkimuksen mukaan hoitohenkilökunnan rooli kielellisten ongelmien paikkaajana ja potilasturvallisuuden varmistajana on suuri, mikä kuormittaa hoitohenkilökuntaa. Maahanmuuttajataustaisen lääkärin kielenoppiminen ja sopeutuminen riippuvat paljon lääkärin asenteesta sekä työyhteisön suhtautumisesta, mikä tekee prosessista haavoittuvan. Nämä seikat osoittavat, että nykytilanne ei ole kestävällä pohjalla. 


\section{TUTKIMUKSEN ARVIOINTIA}

Tutkimuksen kattavuutta voidaan pitää hyvänä, sillä tutkimuksessa ovat edustettuina erilaiset julkisten laitosten tyypit: terveyskeskus, kaupunginsairaala, mielisairaala sekä keskussairaala. Haastateltavien kattavuus varmistettiin kokoamalla kuhunkin haastatteluun moniammatillinen ryhmä. Aineiston keruun luotettavuutta lisää haastateltavien etukäteisvalmistautuminen. Ennakkoon täytetyt lomakkeet toimivat ankkurina haastateltavien yksityisille kokemuksille, jotka haastattelutilanteessa yhdistyivät muiden kokemuksiin (28).

Analyysivaiheen systemaattisuutta vahvistaa haastatteluteemojen koodaus ja koodien yhdistely (20). Näin analyysiprosessi tulee läpinäkyväksi, mikä edesauttaa tulosten toistettavuutta. Tutkimuksessa raportoidut näkemykset toistuivat samansuuntaisina kaikissa haastatteluissa, mikä antaa tuloksille painoarvoa. Eroa löytyi painotuksissa eri henkilökuntaryhmien välillä. Haastateltavien asema työyhteisössä voi vaikuttaa siihen, mitä seikkoja ja millä tavoin haastateltavat tuovat esiin (29). Haastateltavat, joiden toimintaa määrää vahva ohjesääntö tai ammatillinen etiikka, saattavat tuottaa liian positiivista kuvaa omasta ja laitoksensa toiminnasta (20). Kynnys nostaa esiin puutteita oman työpaikan toiminnassa on siis korkea, ja kun se ylitetään, viesti on syytä ottaa vakavasti. Tämä korostaa tämän tutkimuksen sanoman vakavuutta.

Osa monietnisten työyhteisöjen ongelmista ei liity kielitaitoon vaan esimerkiksi kulttuurieroihin ja koulutuksen eroavaisuuksiin $(16,24)$. Tämä tutkimus ei siis tavoita kaikkia ongelmia, joita maahanmuuttajataustaisten lääkärien työskentelyyn liittyy. Lisäksi ne kieliongelmat, jotka ilmenevät lääkärin ja potilaan välisessä suljetussa tilanteessa, voivat jäädä työyhteisöltä piiloon. Tämä saattaa selittää sitä, että sairaalaympäristössä työskentelevät hoitajat kertoivat tutkimuksessa vakavammista tapauksista kuin terveyskeskusympäristössä työskentelevät: terveyskeskuksissa lääkärin vastaanotto on useimmiten suljettu tilanne, jossa muu henkilökunta ei ole läsnä vaan kohtaa potilaan vasta vastaanoton jälkeen. Suljetun vastaanoton kieliongelmia ei tämä tutkimus tavoita, se on menetelmän rajoitus. Sen sijaan tutkimus tuo keskiöön työyhteisön kokemuksen. Kanssatyöntekijöiden kokemukset kielitaito-ongelmista ja niiden yhteinen käsittely haastattelutilanteessa nostavat esiin juuri työelämän näkökulman.

\section{LOPUKSI}

Tutkimuksen perusteella on ilmeistä, että maahanmuuttajalääkärien sujuva integroituminen työyhteisöön vaatii kaikkien osapuolten panostusta. Ennen työelämään siirtymistä maahanmuuttajalääkäreille on oltava tarjolla asianmukaista täydennyskoulutusta ja ammatillisen kielen koulutusta. Riittävä kielitaidon lähtötaso on varmistettava tarkoituksenmukaisella testauksella sellaisella tasolla, joka mahdollistaa itsenäisen kielitaidon kehittämisen työn ohessa. Vaikka alkutilanteen kielitaitotason perusteella ei voida ennustaa, kuinka vahvaksi kielitaito kehittyy ensimmäisten vuosien aikana, alkuvaiheen paremmat valmiudet edesauttavat myös kielitaidon kehittymistä ja keventävät maahanmuuttajalääkärien ja työyhteisöjen taakkaa. Laillistusprosessiin kuuluva työharjoittelu on käytettävä hyödyksi toimintaympäristöön tutustumiseksi ja kielen oppimiseksi, mikä vaatii panostusta niin työyhteisöltä kuin maahanmuuttajataustaiselta lääkäriltä itseltään ja mahdollisesti myös jonkin ulkopuolisen tahon tukea, esimerkiksi kielivalmennusta. Kielitaidon riittävyyden tasosta vastaavat viime kädessä työnantajat, mutta he tarvitsevat luotettavia välineitä lääkärin kielitaidon arvioimiseksi.

Tilanteeseen on tulossa mahdollinen apu, mikäli ulkomailla koulutettujen lääkärien täydennyskoulutusmalli vakiintuu osaksi koulutuspolkua. Sen pilottikoulutuksesta on saatu lupaavia tuloksia (30), ja vastaavien aiemmin järjestettyjen Lääkäriksi Suomeen -koulutusten positiivisista vaikutuksista on viitteitä (15). Virallinen kielitaitovaatimus on vuoden 2016 alusta alkaen laajennettu koskemaan EU/ETA-maiden ulkopuolella koulutettujen lääkärien lisäksi Euroopasta saapuvia lääkäreitä (31). Kielikokeen vaatimustasoon on ehdotettu korotusta (17), mutta myös nykyistä tasoa on puolustettu (15). Tehokkaampi huolehtiminen lääkärien kielitaidosta kaikilla tasoilla palvelisi kuitenkin kaikkia osapuolia, niin maahanmuuttajataustaisia lääkäreitä itseään kuin työyhteisöjä ja ennen kaikkea potilaita.

Yhdeksi terveydenhuollon organisoinnin kannalta olennaiseksi kysymykseksi nousee henkilösuhteiden satunnaisuus ja pysyvyys. Tämän 
tutkimuksen valossa on ilmeistä, että puutteelliseen kielitaitoon liittyvät kommunikointiongelmat korostuvat satunnaisissa kohtaamisissa ja helpottuvat vakiintuneissa henkilösuhteissa. Tämä seikka puoltaa pitkäjänteisiä työsuhteita ja potilas-lääkäri-suhteita. Kiitokset

\section{KIITOKSET}

Kiitos kaikille haastatteluihin osallistuneille sekä niiden järjestämisessä auttaneille henkilöille.

Tervola,M. Institutional perspective on the language skills of immigrant physicians. Sosiaalilääketieteellinen aikakauslehti - Journal of Social Medicine 2017:54: 196-207

The importance of physicians' language skills at work is acknowledged widely but so far there is very limited information on the practical impact of language issues at work. In this study the Finnish language skills of immigrant physicians are approached from the institutional perspective. Group interviews of health care professionals (six interviews, 32 interviewees) were used to find out to what extent the possible language deficiencies of immigrant physicians hinder managing the demands of work, institutional activity and patient safety. Interviews were analyzed with thematic content analysis from the phenomenological perspective.

\section{LÄHTEET}

(1) Lääkäriliiton vuositilasto 2016. Luettu 21.2.2017

(2) Tilastokeskus. Väestörakenne 2016. Luettu 10.8.2017 http://tilastokeskus.fi/til/vaerak/2016/ vaerak_2016_2017-03-29_tau_002_fi.html

(3) Lääkäriliitto. Tietoja maahanmuuttajalääkäreistä Suomessa 2011. Luettu 21.2.2017 http://www.laakariliitto.fi/ site/assets/files/1268/tietoja_ulkomaalaisista_ laakareista_suomessa.pdf

(4) Hammarberg V. Meri-Porissa vieroksutaan ulkomaalaislääkäreitä. Satakunnan kansa 23.1.2015

(5) Sariola S, Kielitaidosta pitää puhua. Lääkärilehti 2012;12:926-929.

(6) Binder P, Borné Y, Johnsdotter S, ym. Shared Language is Essential: Communication in a Multiethnic Obstetric Care Setting. J Health Commun, 2012;17:10:1171-1186. https://doi.org/10.1080/10810730.2012.665421

(7) Wilson E, Chen Hm A, Grumbach K, Wang F, ym. Effects of Limited English Proficiency and Physician Language on Health Care Comprehension. J Gen Intern Med 2005;20(9):800-806.
According to the interviews, physicians' language skills are often considered defective, but this is seen as a natural state of affairs that requires attention and support. Nevertheless, it also burdens the work community, and especially the nursing staff is loaded with too much responsibility. In addition, the patient safety may be threatened. The most problematic situations are patient-physician communication and telephone consultation. Immigrant physicians and work communities are in need of more support to manage the language deficiencies.

Key words: immigrant background, physicians, language skills, language barriers

https://doi.org/10.1111/j.15251497.2005.0174.x

(8) Dorgan KA, Lang F, Floyd M, ym. International medical graduate-patient communication: a qualitative analysis of perceived barriers. Acad Med 2009;84:1567-1575. https://doi.org/10.1097/ ACM.0b013e3181baf5b1

(9) Mahajan J, Stark P. Barriers to education of overseas doctors in paediatrics: a qualitative study in South Yorkshire. Arch Dis Child. 2007 Mar; 92(3): 219-223.

https://doi.org/10.1136/adc.2006.098939

(10) Valvira. ETA/EU-alueen ulkopuolella koulutettujen lääkärein ammattioikeuksien hakemusohje. Luettu 21.2.2017

(11) Kuusio H, Lämsä R, Aalto AM, ym. Inflows of foreign-born physicians and their access to employment and work experiences in health care in Finland: qualitative and quantitative study. Hum Resour Health 2014;12:41. https://doi.org/10.1186/1478-4491-12-41

(12) Tervola M, Pajunen A, Vainio S, ym. Maahanmuuttajataustaisten lääkärien suomen kielen taito laillistamiskuulustelussa. Duodecim 2015;131(4):339-46. 
(13) Haukilahti RL, Virjo I, Mattila K. Lääkärien

laillistaminen - ETA-alueen ulkopuolella

koulutettujen arvio prosessista. Hallinnon tutkimus 2012;31(4),328-337.

(14) Tampereen yliopiston uutiset 9.11.2015. Ulkomaisten lääkäreiden ammatillista kielitaitoa kehitetään uudella mallilla. Luettu 21.2.2017 http://www.uta.fi/med/ajankohtainen. html?id=111329

(15) Seilonen M, Suni M, Härmälä M ym. Ammatillisen kielitaidon arviointikokeilu terveydenhuollon alalla. Kirjassa: Huhta A, Hildén R. Kielitaidon arviointitutkimus 2000-luvun Suomessa. AFinLA-e. Soveltavan kielitieteen tutkimuksia 2016. Nro 9,110-141.

(16) Aalto AM, Elovainio M, Heponiemi T, ym Ulkomaalaistaustaiset lääkärit ja hoitajat suomalaisessa terveydenhuollossa. Haasteet ja mahdollisuudet. Terveyden ja hyvinvoinnin laitos. Raportti 2013;7.

(17) Opetus- ja kulttuuriministeriö. Kielitaidon määrittäminen sekä kielitaidon ja EU/ETAalueen ulkopuolella hankitun koulutuksen täydentäminen terveysalalla. Opetus- ja kulttuuriministeriön työryhmämuistioita ja -selvityksiä 2014:5. Helsinki: Opetus- ja kulttuuriministeriö. http://www.minedu.fi/OPM/ Julkaisut/2014/kielitaito_terveysalalla.html

(18) Sommer J, Macdonald W, Bulsara C, ym. Grunt language versus accent: The percieved communication barriers between international medical graduates and patients in Central Wheatbelt catchments. Aust J Prim Health. 2012;18(3):197-203. https://doi.org/10.1071/PY11030

(19) Merton RK, Fiske M, Kendall PL. The Focused Interview. A manual of problems and procedures. Glencoe, IL: Free Press; 1990 [1956].

(20) Hirsijärvi S, Hurme H. Tutkimushaastattelu. Teemahaastattelun teoria ja käytäntö. Helsinki: Gaudeamus; 2014.

(21) Nielsen K. The Qualitative Research Interview and Issues of Knowledge. Nord Psychol 2007;59(3):210-222. https://doi.org/10.1027/1901-2276.59.3.210

(22) Tuomi J, Sarajärvi A. Laadullinen tutkimus ja sisällönanalyysi. Vantaa: Tammi; 2009.

(23) Alastalo M, Åkerman M.

Asiantuntijahaastattelun analyysi: Faktojen jäljillä. Kirjassa: Ruusuvuori J, Nikander
P. (toim.) Haastattelun analyysi. Tampere: Vastapaino; 2010.

(24) Pitkänen P. Terveydenhuollon kansainvälistyvät toimintaympäristöt. Kirjassa: Pitkänen P. (toim.) Kulttuurien kohtaaminen arjessa. Tampere: Vastapaino. 2011, 75-100.

(25) Bergbom B, Toivana M, Airila A ym. Monimuotoisuusbarometri 2016. Fokuksessa monikulttuurisuus ja osaaminen 2016. Helsinki: Työterveyslaitos.

(26) Eggly S, Musial J, Smulowitz J. Research and Discussion Note. The Relationship between English Language Proficiency and Success as a Medical Resident. English for Specific Purposes 1999;18(2),201-208. https://doi.org/10.1016/S0889-4906(98)00002-7

(27) Chur-Hansen A, Vernon-Roberts J, Clark S. Language background, English language proficiency and medical communication skills of medical students. Med Educ 1997;31,259-263. https://doi.org/10.1111/j.1365-2923.1997. tb02922.x

(28) Pietilä I. Ryhmä- ja yksilöhaastattelun diskursiivinen analyysi. Kirjassa: Ruusuvuori J, Nikander P. (toim.) Haastattelun analyysi. Tampere: Vastapaino; 2010.

(29) Sarangi S, Roberts C. The dynamics of interactional and institutional orders in workrelated settings. Kirjassa: Heller M, Watts RJ. (toim.) Talk, Work and Institutional Order, Discourse in Medical, Mediation and Management Settings. Berlin: Mouton de Gruyter; 1999, 1-57. https://doi.org/10.1515/9783110208375

(30) Nurmi R. Eikö lääkäri ymmärtänyt mitä sanoit? - Kohta ymmärtää, sillä maahanmuuttajalääkärit pääsevät kielioppiin. YLE Uutiset 16.8.2016. Luettu 28.2.2017 http:// yle.fi/uutiset/3-9096334

(31) Valvira. Language requirements. Luettu 28.2.2017 https://www.valvira.fi/web/en/ healthcare/professional_practice_rights/ language_requirements

MAIJA TERVOLA
FM, Yliopisto-opettaja, väitöskirjatutkija
Tampereen yliopisto
Viestintätieteiden tiedekunta

Maija Tervola

Tampereen yliopisto

Viestintätieteiden tiedekunta 


\section{Valvira valvoo ulkomailla lääkärintutkinnon suorittaneiden ammattioikeuksia}

Kaikilta ulkomailla koulutetuilta lääkäreiltä vaaditaan ammatinharjoittamisoikeuden saamiseksi

o tutkintotodistuksen tunnustaminen

○ kielikokeen suorittaminen hyväksytysti (Yleisten kielitutkintojen taso 3) - Huom! 1.1.2016 lähtien kielikoe vaaditaan myös EU-lääkäreiltä.

EU/ETA-maiden ulkopuolelta tulevalta lääkäriltä vaaditaan edellisten lisäksi

○ 6 kk:n harjoittelu julkisessa terveydenhuollossa Suomessa

- kolmen laillistuskuulustelun suorittaminen hyväksytysti.

Lähde: Valvira, Terveydenhuollon ammattioikeudet http://www.valvira. fi/terveydenhuolto/ammattioikeudet 